ARTICLE

https://doi.org/10.1038/s41467-018-07903-6

\title{
9.2\%-efficient core-shell structured antimony selenide nanorod array solar cells
}

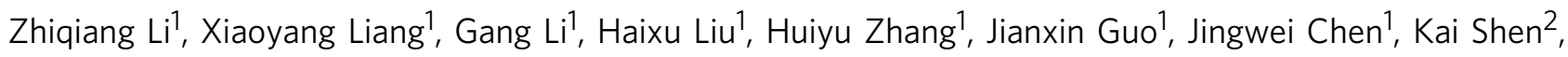
Xingyuan San', Wei Yư ${ }^{1}$, Ruud E.I. Schropp (i) ${ }^{2} \&$ Yaohua Mai ${ }^{2}$

Antimony selenide $\left(\mathrm{Sb}_{2} \mathrm{Se}_{3}\right)$ has a one-dimensional (1D) crystal structure comprising of covalently bonded $\left(\mathrm{Sb}_{4} \mathrm{Se}_{6}\right)_{n}$ ribbons stacking together through van der Waals force. This special structure results in anisotropic optical and electrical properties. Currently, the photovoltaic device performance is dominated by the grain orientation in the $\mathrm{Sb}_{2} \mathrm{Se}_{3}$ thin film absorbers. Effective approaches to enhance the carrier collection and overall power-conversion efficiency are urgently required. Here, we report the construction of $\mathrm{Sb}_{2} \mathrm{Se}_{3}$ solar cells with high-quality $\mathrm{Sb}_{2} \mathrm{Se}_{3}$ nanorod arrays absorber along the [001] direction, which is beneficial for sun-light absorption and charge carrier extraction. An efficiency of $9.2 \%$, which is the highest value reported so far for this type of solar cells, is achieved by junction interface engineering. Our cell design provides an approach to further improve the efficiency of $\mathrm{Sb}_{2} \mathrm{Se}_{3}$-based solar cells.

\footnotetext{
${ }^{1}$ Hebei Key Laboratory of Optic-Electronic Information Materials, College of Physics Science and Technology, Hebei University, Baoding 071002, China. 2 Institute of New Energy Technology, College of Information Science and Technology, Jinan University, Guangzhou 510632, China. These authors contributed equally: Zhiqiang Li, Xiaoyang Liang, Gang Li. Correspondence and requests for materials should be addressed to Z.L. (email: lizhiqiang@hbu.edu.cn) or to Y.M. (email: yaohuamai@jnu.edu.cn)
} 
A mong inorganic semiconductor thin film photovoltaics, cadmium telluride (CdTe) and copper indium gallium selenide $\left(\mathrm{Cu}(\mathrm{In}, \mathrm{Ga}) \mathrm{Se}_{2}\right)$ solar cells have reached powerconversion efficiencies of over $22 \%{ }^{1,2}$. The high device performance is possible due to the enough photon absorption, high bulk lifetime, superior carrier collection efficiency, and excellent junction interface. The chalcogenide antimony selenide $\left(\mathrm{Sb}_{2} \mathrm{Se}_{3}\right)$ recently emerged as a promising alternative light-absorber material for high-efficiency photovoltaic devices due to its attractive properties, such as a single phase structure, proper optical bandgap (1.1-1.3 eV), high light absorption coefficient $\left(10^{5} \mathrm{~cm}^{-1}\right.$ at around $\left.600 \mathrm{~nm}\right)$, low toxicity, and high element abundance ${ }^{3-8}$. The use of the chalcogenide $\mathrm{Sb}_{2} \mathrm{Se}_{3}$ avoids the issue of low In and Ga availability. The application of $\mathrm{Sb}_{2} \mathrm{Se}_{3}$ in photovoltaic devices as light-absorber was explored by Nair et al. in 2000 s, yielding a rather low conversion efficiency of $0.66 \% 9,10$. Since the notable efficiency values of $3.21 \%$ and $2.26 \%$ obtained in 2014 by Choi et al. and Zhou et al., respectively, $\mathrm{Sb}_{2} \mathrm{Se}_{3}$-based solar cells have experienced rapid development ${ }^{3,11}$. A powerconversion efficiencies of $6.0 \%$ was reported for a zinc oxide $(\mathrm{ZnO}) / \mathrm{Sb}_{2} \mathrm{Se}_{3}$ heterojunction and $6.5 \%$ for a cadmium sulfide (CdS) $/ \mathrm{Sb}_{2} \mathrm{Se}_{3}$ heterojunction with $\mathrm{PbS}$ quantum dot film as holetransporting layer, respectively ${ }^{12,13}$. Moreover, a $7.6 \%$ efficiency was reported this year, due to an improved crystallinity of $\mathrm{Sb}_{2} \mathrm{Se}_{3}$ thin film absorbers ${ }^{14}$. However, for $\mathrm{Sb}_{2} \mathrm{Se}_{3}$ to become a low cost, high abundancy compound to replace $\mathrm{Cu}(\mathrm{In}, \mathrm{Ga}) \mathrm{Se}_{2}$, this value is still too much behind that of state-of-the-art $\mathrm{Cu}(\mathrm{In}, \mathrm{Ga}) \mathrm{Se}_{2}$ solar cells. We here present a concept based on growing $\mathrm{Sb}_{2} \mathrm{Se}_{3}$ nanorod arrays that can lead to fundamentally improved solar cells. This method thus far had led to cells with a certified efficiency of $9.2 \%$.

One attractive feature of $\mathrm{Sb}_{2} \mathrm{Se}_{3}$ is that it has a one-dimensional (1D) crystal structure and highly anisotropic properties. The $\mathrm{Sb}_{2} \mathrm{Se}_{3}$ crystal consists of ribbon-like $\left(\mathrm{Sb}_{4} \mathrm{Se}_{6}\right)_{n}$ units linked through van der Waals forces in the [010] and [100] direction, while strong covalent $\mathrm{Sb}-\mathrm{Se}$ bonds make the units holding together in the [001] direction ${ }^{3,15}$. This apparently directiondependent bonding nature will result in significant anisotropy. Theoretical calculation revealed that the surfaces parallel to the [001] direction, such as (110), (120) surfaces, have lower formation energies than the other surfaces and were terminated with surfaces free of dangling bonds ${ }^{15}$. Moreover, theoretical calculations and experimental results exhibited that carrier transport in the [001] direction is much easier than that in other directions ${ }^{15,16}$. Thus, the devices are expected to offer appealing photoresponse and device performance if the $\mathrm{Sb}_{2} \mathrm{Se}_{3}$ absorber consists of $\left(\mathrm{Sb}_{4} \mathrm{Se}_{6}\right)_{n}$ ribbons stacked vertically on the substrate. However, up to date, only quality [221]-oriented absorbers have been fabricated, in which the $\left(\mathrm{Sb}_{4} \mathrm{Se}_{6}\right)_{n}$ ribbons were tilted and have a certain degree with the substrate. On the other hand, the optimal $\mathrm{Sb}_{2} \mathrm{Se}_{3}$ absorber thickness for these devices were limited to the range of $0.3-0.6 \mu \mathrm{m}$ due to the electron diffusion length $\left(L_{\mathrm{e}}\right)$ of only $0.3 \mu \mathrm{m}$ in the [221] direction ${ }^{16}$. Due to this effect, the higher electron diffusion length $L_{\mathrm{e}}$ along the [001] direction, which approaches $1.7 \mu \mathrm{m}$ (five times that along the [221] direction $\left.^{16}\right)$, could thus far not be fully exploited.

In this work, we address this limitation and grew $\mathrm{Sb}_{2} \mathrm{Se}_{3}$ nanorod arrays and solar cells with [001]-orientation on Mocoated glass substrates using the close spaced sublimation (CSS) technique. A growth model is presented to investigate the mechanism covering the stages from atom absorption at the Mo surface to growth of the thin film structure towards the formation of aligned $1 \mathrm{D} \mathrm{Sb}_{2} \mathrm{Se}_{3}$ nanorod arrays. We investigated the junction structure of the $\mathrm{CdS} / \mathrm{Sb}_{2} \mathrm{Se}_{3}$ nanorod interface. We here reveal the migration of element antimony $(\mathrm{Sb})$ into the whole $\mathrm{CdS}$ buffer layer if no specific precautions are taken. Subsequently, we introduce a very thin titanium oxide $\left(\mathrm{TiO}_{2}\right)$ layer deposited by atomic layer deposition (ALD) technique at the $\mathrm{CdS} / \mathrm{Sb}_{2} \mathrm{Se}_{3}$ junction interface. The interface engineering with $\mathrm{TiO}_{2}$ leads to an independently verified record power-conversion efficiency of 9.2\% for the $\mathrm{Sb}_{2} \mathrm{Se}_{3}$ solar cells $\left(\mathrm{ZnO}: \mathrm{Al} / \mathrm{ZnO} / \mathrm{CdS} / \mathrm{TiO}_{2} / \mathrm{Sb}_{2} \mathrm{Se}_{3}\right.$ nanorod arrays $/ \mathrm{MoSe}_{2} / \mathrm{Mo}$ ) with an absorber thickness over 1000 $\mathrm{nm}$ while maintaining a high fill factor of $70.3 \%$. The values of external quantum efficiency (EQE) are higher than $85 \%$ in a wide spectral range from 550 to $900 \mathrm{~nm}$, approximating the values of well-developed $\mathrm{CdS} / \mathrm{Cu}(\mathrm{In}, \mathrm{Ga}) \mathrm{Se}_{2}$ thin film solar cells. This work can facilitate the preparation and application of patterned 1D $\mathrm{Sb}_{2} \mathrm{Se}_{3}$-based nanostructures for applications in sensor arrays, piezoelectric antenna arrays, and other electronic and optoelectronic devices.

\section{Results}

Characterization of $\mathbf{S b}_{2} \mathrm{Se}_{3}$ nanorod arrays. It is worth noting that, to our knowledge, the fabrication of high quality ribboned $\mathrm{Sb}_{2} \mathrm{Se}_{3}$ nanorod arrays on Mo-coated glass substrate by the CSS technique has not been previously reported. The surface and cross-sectional morphologies of the as-deposited $\mathrm{Sb}_{2} \mathrm{Se}_{3}$ nanorod arrays were characterized by scanning electron microscope (SEM) in Fig. 1a, b, respectively. A high density array of $\mathrm{Sb}_{2} \mathrm{Se}_{3}$ nanorods grown vertically on the substrate with diameters ranging from 100 to $300 \mathrm{~nm}$ and lengths of about $1200 \mathrm{~nm}$ was observed. The crystal structure and phase purity of the $\mathrm{Sb}_{2} \mathrm{Se}_{3}$ nanorod arrays were measured by X-ray diffraction (XRD) as depicted in Fig. 1c. The arrays exhibit the orthorhombic crystal geometry belonging to the space group of Pbnm (JCPDS 15-0861) with no detectable impurities of other phases. It is important to note that only strong $(h k 1)$ and $(h k 2)$ diffraction peaks are observed in the XRD pattern, suggesting that the $\mathrm{Sb}_{2} \mathrm{Se}_{3}$ nanorod arrays have a preferred orientation along the $c$-axis direction. The intensity ratios of $I_{101} /$ $I_{221}$ and $I_{002} / I_{221}$ for the nanorod arrays reached 0.42 and 0.73 , respectively. These ratios are much higher than those of thin films with the (221)-preferred orientation in previous reports ${ }^{12,17}$. Since the (221)-oriented grain consists of $\left(\mathrm{Sb}_{4} \mathrm{Se}_{6}\right)_{n}$ ribbons grown vertically to the substrate with a tilt angle, the increased $I_{101} / I_{221}$ and $I_{002} / I_{221}$ values hint that the $\mathrm{Sb}_{2} \mathrm{Se}_{3}$ nanorod arrays are grown with enhanced preference along the $c$-axis [001] direction and at a higher tilt angle between $\left(\mathrm{Sb}_{4} \mathrm{Se}_{6}\right)_{n}$ ribbons and the substrate, compared to the (221)-oriented thin films ${ }^{4,15}$. We further relied on high-resolution transmission electron microscopy (HRTEM) to reveal the crystal orientation of the individual $\mathrm{Sb}_{2} \mathrm{Se}_{3}$ nanorods. Samples were cross-sectioned by focused ion beam and a TEM image of the nanorod array is shown in Fig. 1d. The interplanar d-spacings of $0.389 \mathrm{~nm}$ and $0.521 \mathrm{~nm}$ correspond to the (001) and (210) planes of orthorhombic $\mathrm{Sb}_{2} \mathrm{Se}_{3}$, respectively, as shown in Fig. 1e, which is consistent with the 1D singlecrystalline $\mathrm{Sb}_{2} \mathrm{Se}_{3}$ nanostructures synthesized by chemical synthesis methods ${ }^{18,19}$. The corresponding selected-area electron diffraction (SAED) pattern (Fig. 1f) exhibited the vertical relationship of the (001) and (210) planes, indicating the $[1 \overline{2} 0]$ crystallographic axis of the Pbnm space group and the $\mathrm{Sb}_{2} \mathrm{Se}_{3}$ nanorod, suggesting that the $\mathrm{Sb}_{2} \mathrm{Se}_{3}$ nanorod arrays in this work grow along the [001] direction. Analysis on additional $\mathrm{Sb}_{2} \mathrm{Se}_{3}$ nanorods further supported that the $\mathrm{Sb}_{2} \mathrm{Se}_{3}$ nanorod arrays were grown along the [001] direction (Supplementary Figure 1). The SAED characterization provides a direct observation of the atomic arrangement of the $\mathrm{Sb}_{2} \mathrm{Se}_{3}$ nanorod and echoes previous XRD and SEM results.

Growth model of $\mathrm{Sb}_{2} \mathrm{Se}_{3}$ nanorod arrays on Mo substrate. As shown in Fig. 2, a series of plan-view and cross-sectional SEM images of $\mathrm{Sb}_{2} \mathrm{Se}_{3}$ grown with different durations on Mo substrate 

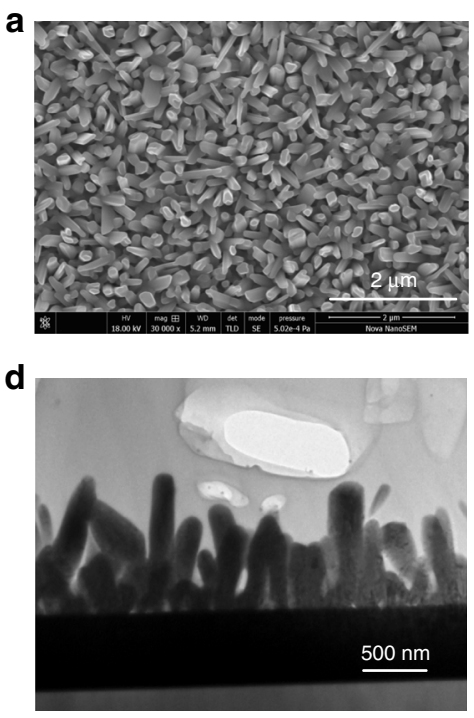

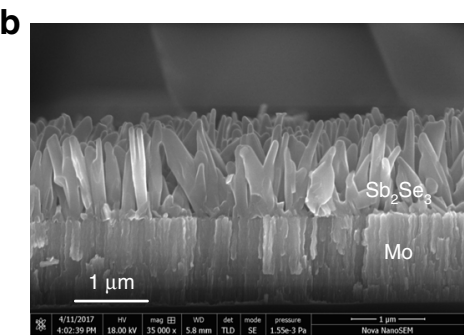

e

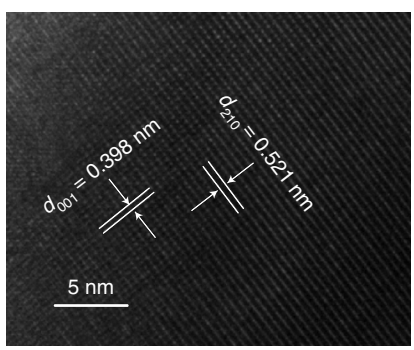

C
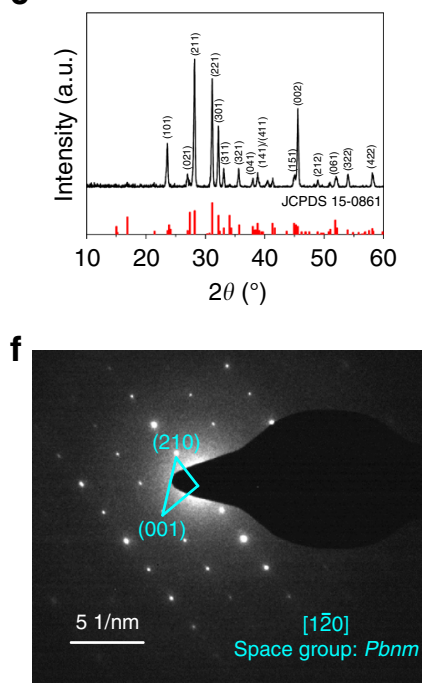

Fig. 1 Microscopy and spectroscopy of $\mathrm{Sb}_{2} \mathrm{Se}_{3}$ nanorod array. a-c Top-view (a), cross-sectional (b), SEM images and X-ray diffraction pattern (c) of the $\mathrm{Sb}_{2} \mathrm{Se}_{3}$ nanorod arrays grown on Mo-coated glass substrate. d-f TEM image (d), high resolution TEM (HRTEM) image (e), and the corresponding selected-area electron diffraction (SAED) pattern (f) of the $\mathrm{Sb}_{2} \mathrm{Se}_{3}$ nanorod array
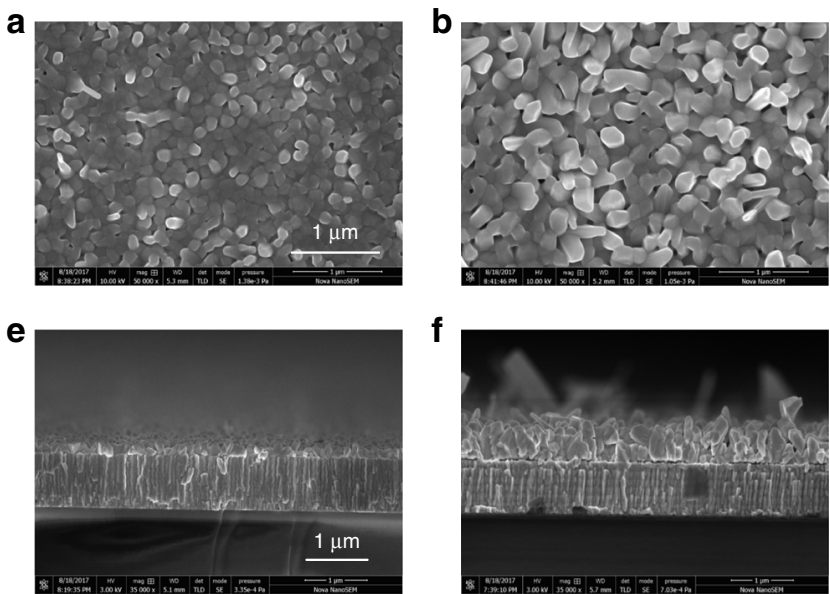
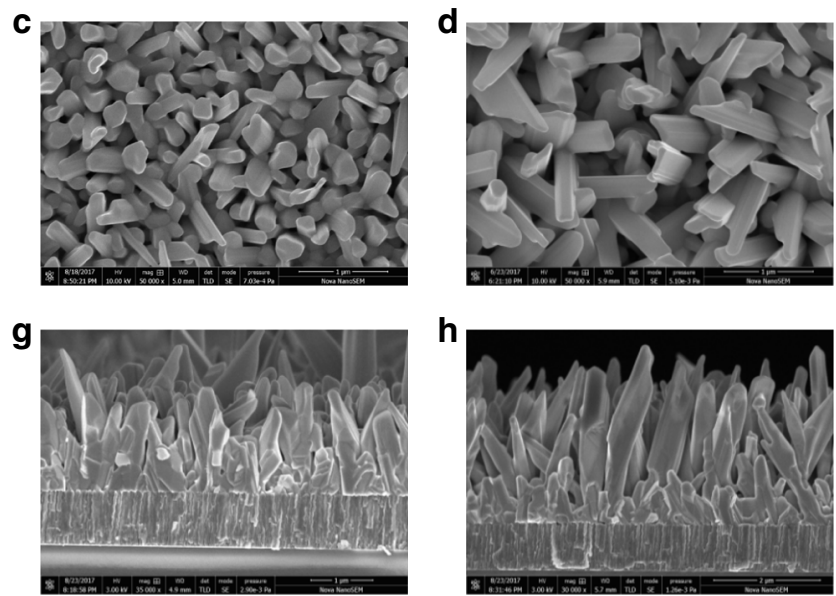

Fig. 2 Morphology evolution of $\mathrm{Sb}_{2} \mathrm{Se}_{3}$ : from thin film to nanorod array. a-d Top-view SEM images of $\mathrm{Sb}_{2} \mathrm{Se}_{3}$ with different deposition times, a $60 \mathrm{~s}$, b $120 \mathrm{~s}$, c $160 \mathrm{~s}$, and $\mathbf{d} 180 \mathrm{~s}$. e-h The corresponding cross-sectional images of $\mathrm{Sb}_{2} \mathrm{Se}_{3}$ with different deposition time, e $60 \mathrm{~s}, \mathbf{f} 120 \mathrm{~s}, \mathbf{g} 160 \mathrm{~s}$, and h $180 \mathrm{~s}$. The scale bar for $\mathbf{a}-\mathbf{h}$ is $1 \mu \mathrm{m}$

exhibit the morphological evolution of $\mathrm{Sb}_{2} \mathrm{Se}_{3}$. It was found that with increasing growth durations from 60 to $180 \mathrm{~s}$ the morphologies of $\mathrm{Sb}_{2} \mathrm{Se}_{3}$ samples vary from a compact thin film structure to an aligned nanorod array structure. As seen from the corresponding cross-sectional images, the thickness of the $\mathrm{Sb}_{2} \mathrm{Se}_{3}$ layer was 200,600, 1000 and $2000 \mathrm{~nm}$ for the samples grown for $60,120,160$ and $180 \mathrm{~s}$, respectively. It indicates that both thickness and growth rate are increased as the deposition proceeds. The CSS-processed $\mathrm{Sb}_{2} \mathrm{Se}_{3}$ is a smooth and compact film composed of grains with uniform grain size of about $100 \mathrm{~nm}$ in the first $60 \mathrm{~s}$ (Fig. 2a, e). When the growth time increases to $120 \mathrm{~s}$, the grain size increases to $200-300 \mathrm{~nm}$ and the sample still displays film structure morphology, though the surface becomes porous and some craters can be observed (Fig. 2b, f). For the sample grown for $160 \mathrm{~s}$ (Fig. 2c, g), it is observed that the $\mathrm{Sb}_{2} \mathrm{Se}_{3}$ consists of a compact bottom layer and a nanorod-array top layer vertical to the substrate. The vertical nanorod array appears to grow on top of the compact bottom layer. As the growth times increases further, to $180 \mathrm{~s}$, the thickness of the top nanorod-array layer increases while the compact bottom layer thickness shrinks (Fig. 2d, h).

Based on the above observation, we propose a model to understand the mechanism governing the transition in the growth process from $\mathrm{Sb}_{2} \mathrm{Se}_{3}$ thin film to nanorod array. The growth process of $\mathrm{Sb}_{2} \mathrm{Se}_{3}$ can be divided into four stages: surface absorption, film growth, splitting, and nanorod array growth stage. For the first (surface absorption) stage, we have generated an atomistic model shown in Fig. 3a based on the following considerations: first, $\mathrm{Sb}_{2} \mathrm{Se}_{3}$ possesses a $1 \mathrm{D}$ crystal structure and is comprised of $\left(\mathrm{Sb}_{4} \mathrm{Se}_{6}\right)_{n}$ ribbons. Considering the combination between the $\left(\mathrm{Sb}_{4} \mathrm{Se}_{6}\right)_{n}$ ribbon and the substrate surface, we calculated the atom displacement distributions by the Vienna ab initio Simulation Package (VASP) ${ }^{20}$. The calculated results show that the $\mathrm{Sb}$ and $\mathrm{Se}$ atoms are dispersed from $\mathrm{Sb}_{4} \mathrm{Se}_{6}$ and scattered on the Mo surface and that the ribboned structure of $\mathrm{Sb}_{4} \mathrm{Se}_{6}$ collapses if the $\mathrm{Sb}_{4} \mathrm{Se}_{6}$ unit runs parallel to the Mo (110) surface (Supplementary Figure 2 and Supplementary Figure 3a). On the contrary, when the $\mathrm{Sb}_{4} \mathrm{Se}_{6}$ unit is standing vertically on the Mo 
(110) plane, the simulated results display that the unit is stable with lower distortion (Supplementary Figure $3 \mathrm{~b}$ ). Second, despite the decomposition of $\mathrm{Sb}_{2} \mathrm{Se}_{3}$ during the thermal process, the absorption of $\mathrm{Sb}$ or $\mathrm{Se}$ atoms at the $\mathrm{Sb}_{4} \mathrm{Se}_{6} / \mathrm{Mo}$ interface is also taken into account. The degree of lattice deformation for the $\mathrm{Sb}_{4} \mathrm{Se}_{6} / \mathrm{Mo}, \mathrm{Sb}_{4} \mathrm{Se}_{6} / \mathrm{Sb} / \mathrm{Mo}$ and $\mathrm{Sb}_{4} \mathrm{Se}_{6} / \mathrm{Se} / \mathrm{Mo}$ absorption models, respectively, is $0.755,0.642$ and 0.534 . This indicates that on the Mo surface the absorption of one Se atom layer prior to $\left(\mathrm{Sb}_{4} \mathrm{Se}_{6}\right)_{n}$ ribbons is favored rather than the vertical growth of $\left(\mathrm{Sb}_{4} \mathrm{Se}_{6}\right)_{n}$


Fig. 3 Growth model of the $\mathrm{Sb}_{2} \mathrm{Se}_{3}$ nanorod arrays on Mo substrate. a Atomistic model of $\mathrm{Sb}_{4} \mathrm{Se}_{6}$ unit on the (110) plane of Mo. b-d Schematics of the $\mathrm{Sb}_{2} \mathrm{Se}_{3}$ at different growth stages, $\mathbf{b}$ thin film growth, $\mathbf{c}$ split, and d nanorod array growth (top part exhibits obvious nanorod array morphology and bottom is compact layer) ribbons (Supplementary Figure 3c, 3d and Supplementary Table 1).

During film growth, splitting, and nanorod growth stages, the $\mathrm{Sb}_{2} \mathrm{Se}_{3}$ grains grow bigger as $\mathrm{Sb}_{2} \mathrm{Se}_{3}$ vapor continuously evaporates from the $\mathrm{Sb}_{2} \mathrm{Se}_{3}$ source, and then the transition from thin film to nanorod growth occurs when the generated lateral stress beyond the tolerance of the van der Waals forces between the $\left(\mathrm{Sb}_{4} \mathrm{Se}_{6}\right)_{n}$ ribbons in the deposited $\mathrm{Sb}_{2} \mathrm{Se}_{3}$ films. The nanorods get longer and more in number and the splitting goes deeper into the film as the growth time proceeds (Fig. 3d), which could be attributed to the higher growth rate in the ribbon direction due to the stronger covalent $\mathrm{Sb}-\mathrm{Se}$ bonds internally in the ribbon.

Device performance and characterization. To investigate the effect of different absorber morphologies on the performance of the $\mathrm{Sb}_{2} \mathrm{Se}_{3}$ solar cells, the devices were finished by successively depositing the CdS buffer, high-resistance (HR) and lowresistance (LR) $\mathrm{ZnO}$ layer, and front $\mathrm{Ag}$ contact. The devices were divided into three groups according to the thicknesses and morphologies of the CSS-processed $\mathrm{Sb}_{2} \mathrm{Se}_{3}$ absorbers. For description clarity, we denoted the $\mathrm{Sb}_{2} \mathrm{Se}_{3}$ thin film absorbers with thickness between 200 and $600 \mathrm{~nm}$ as $\mathrm{TF}-\mathrm{Sb}_{2} \mathrm{Se}_{3}$, the $\mathrm{Sb}_{2} \mathrm{Se}_{3}$ thickness in the range of 650 to $1100 \mathrm{~nm}$, comprising a double layer (vertical nanorod-array top layer and compact-film bottom layer) as $\mathrm{M}-\mathrm{Sb}_{2} \mathrm{Se}_{3}$, and $\mathrm{Sb}_{2} \mathrm{Se}_{3}$ absorbers thicker than $1100 \mathrm{~nm}$ with nearly an entire nanorod-array structure as $\mathrm{NA}-\mathrm{Sb}_{2} \mathrm{Se}_{3}$.

Figure $4 \mathrm{a}$ displays representative current density-voltage $(J-V)$ curves of the solar cells employing the TF-Sb $\mathrm{Se}_{3}, \mathrm{M}-\mathrm{Sb}_{2} \mathrm{Se}_{3}$, and $\mathrm{NA}-\mathrm{Sb}_{2} \mathrm{Se}_{3}$ absorbers, respectively. Typical $J-V$ characterizations performed under standard test conditions (STC) yielded an optimal conversion efficiency of $4.78 \%$ for the $\mathrm{M}-\mathrm{Sb}_{2} \mathrm{Se}_{3}$ solar cell with an open circuit voltage $\left(V_{\mathrm{OC}}\right)$ of $0.370 \mathrm{~V}$, short circuit current density $\left(J_{\mathrm{SC}}\right)$ of $27.43 \mathrm{~mA} \mathrm{~cm}^{-2}$, and fill factor (FF) of $47.46 \%$ (see Table 1). The NA-Sb $\mathrm{Se}_{3}$ samples show substantially
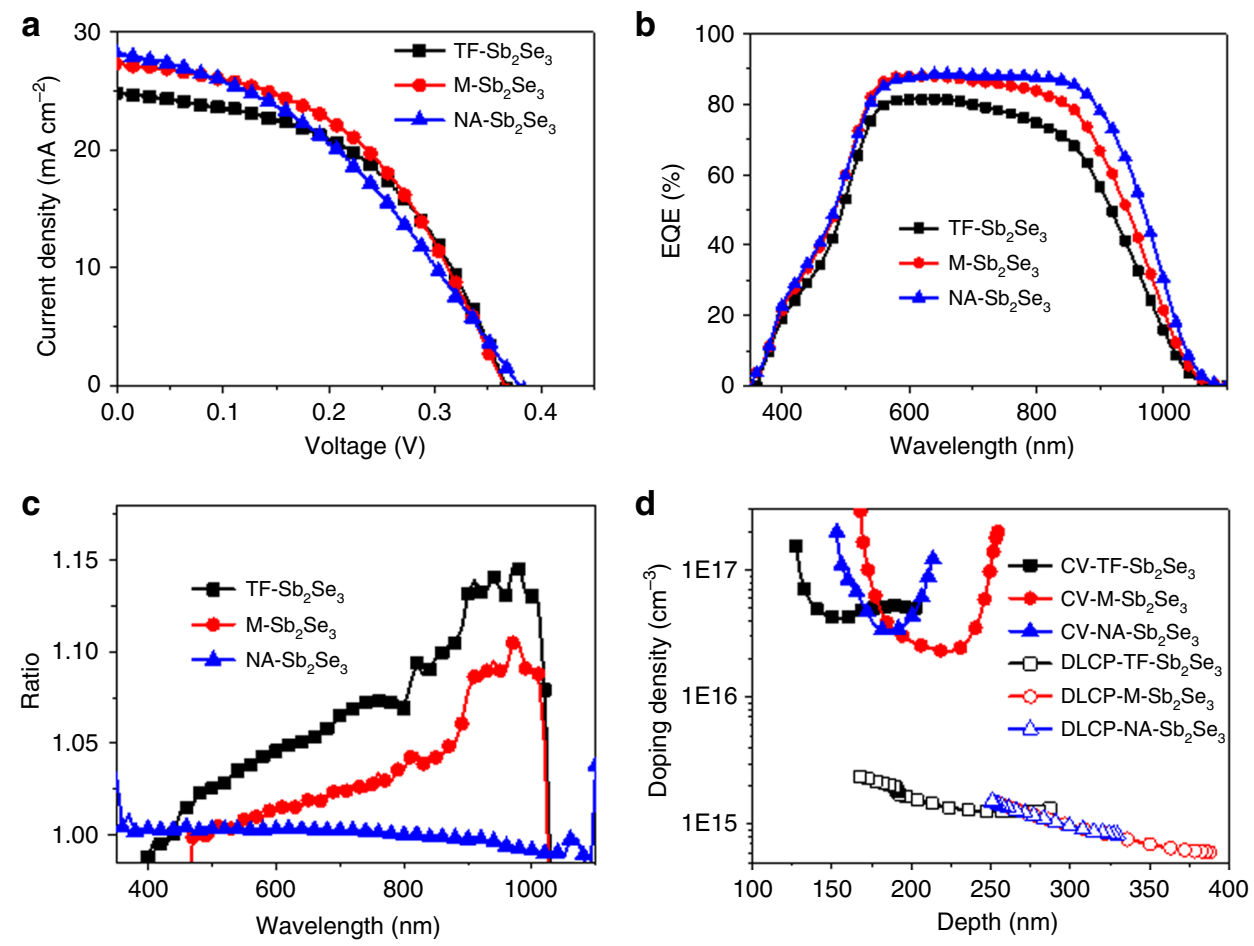


$\mathrm{EQE}$ spectra and the ratio of $\mathrm{EQE}(-0.5 \mathrm{~V}) / \mathrm{EQE}(\mathrm{OV})$ curves of the solar cells. $\mathbf{d} \mathrm{C}-\mathrm{V}$ profiling and DLCP profiling of the solar cells 
Table 1 Photovoltaic performance parameters for the $\mathrm{Sb}_{2} \mathrm{Se}_{3}$ solar cells with different absorber structure (Fig. 4a)

\begin{tabular}{lllll} 
Absorber & $\boldsymbol{V}_{\mathbf{o c}}(\mathbf{V})$ & $\boldsymbol{J}_{\mathbf{s c}}(\mathbf{m A ~ c m}$ \\
\hline $\mathrm{TF}-\mathrm{Sb}_{2} \mathrm{Se}_{3}$ & 0.368 & 24.87 & Fill factor & Efficiency (\%) \\
$\mathrm{M}-\mathrm{Sb}_{2} \mathrm{Se}_{3}$ & 0.370 & 27.34 & 49.53 & 4.53 \\
$\mathrm{NA}-\mathrm{Sb}_{2} \mathrm{Se}_{3}$ & 0.382 & 28.60 & 47.46 & 4.78 \\
\end{tabular}

reduced $\mathrm{FF}$, which may be attributed to strong $\mathrm{CdS} / \mathrm{Sb}_{2} \mathrm{Se}_{3}$ interface recombination.

The presence of the nanorod structure in the absorbers increases the $J_{\mathrm{SC}}$ of the solar cells, which is mainly due to the enhanced long wavelength response (Fig. $4 \mathrm{~b}$ ). The rough surface of the thicker nanorod absorber enhances the light harvesting and thus reduces the optical reflection (Supplementary Figure 4$)^{21}$. At the same time, the [001] preferential orientation of the nanorods facilitates long-range carrier transport along the $\left(\mathrm{Sb}_{4} \mathrm{Se}_{6}\right)_{n}$ ribbons and thus guarantees carrier extraction and high $J_{\mathrm{SC}}{ }^{16}$. This is also supported by the EQE and biased EQE results. As shown in Fig. $4 \mathrm{~b}$, the EQE spectrum of the TF- $\mathrm{Sb}_{2} \mathrm{Se}_{3}$ device reaches a maximum value of $80 \%$ at about $550 \mathrm{~nm}$, then declines both at shorter and longer wavelength due to the strong absorption of the CdS buffer and the insufficient generation and/or collection of carriers at the back side, respectively. This observation is consistent with previous reports of $\mathrm{Sb}_{2} \mathrm{Se}_{3}$-based thin film solar cells ${ }^{22,23}$. For the $\mathrm{M}-\mathrm{Sb}_{2} \mathrm{Se}_{3}$ device, the maximum value of $\mathrm{EQE}$ reaches $88 \%$ at approximately $550 \mathrm{~nm}$, higher than that of the TF$\mathrm{Sb}_{2} \mathrm{Se}_{3}$ device, partly due to its lower reflectance. The EQE spectra of the $\mathrm{NA}-\mathrm{Sb}_{2} \mathrm{Se}_{3}$ device demonstrates a relatively wide $\mathrm{EQE}$ plateau with values approaching $87 \%$ between 550 and $900 \mathrm{~nm}$, and a gradual decrease towards longer wavelengths. EQE spectra were also measured under bias-voltage conditions $(-0.5 \mathrm{~V})$, and the curves describing the ratio of EQE $(-0.5 \mathrm{~V})$ over EQE $(0 \mathrm{~V})$ are shown in Fig. 4c. For the NA-Sb $\mathrm{Se}_{3}$ device, the EQE ratio is approximately unity over the whole spectral range, while that of the $\mathrm{TF}-\mathrm{Sb}_{2} \mathrm{Se}_{3}$ and $\mathrm{M}-\mathrm{Sb}_{2} \mathrm{Se}_{3}$ devices is strongly bias dependent, especially at long wavelength. This indicates that the photogenerated carriers in the latter devices are not collected completely and the collection requires an internal electric field. The high and wide plateau and its weak bias-voltage dependence of the $\mathrm{EQE}$ spectrum of $\mathrm{NA}-\mathrm{Sb}_{2} \mathrm{Se}_{3}$ device reveals that the carrier collection is highly efficient for the $\mathrm{Sb}_{2} \mathrm{Se}_{3}$ nanorod array structure along the [001] direction, explaining the higher $J_{\mathrm{SC}}$ value of the NA-Sb${ }_{2} \mathrm{Se}_{3}$ device compared to that of the $\mathrm{M}-\mathrm{Sb}_{2} \mathrm{Se}_{3}$ device.

We then turned to the issue of the junction properties of the $\mathrm{TF}-\mathrm{Sb}_{2} \mathrm{Se}_{3}, \mathrm{M}-\mathrm{Sb}_{2} \mathrm{Se}_{3}$ and $\mathrm{NA}-\mathrm{Sb}_{2} \mathrm{Se}_{3}$ solar cells. In order to understand their $\mathrm{AC}$ behavior, an equivalent circuit model was introduced. It consists of serial conductance, junction conductance and the capacitance element, which mainly includes the junction interface and trapping state induced capacitance. (Supplementary Figure 5). The junction capacitance is frequency independent while trapping capacitance is strongly frequencydependent ${ }^{24-26}$. In comparison with the TF- $\mathrm{Sb}_{2} \mathrm{Se}_{3}$, the $\mathrm{M}-\mathrm{Sb}_{2} \mathrm{Se}_{3}$ and $\mathrm{NA}-\mathrm{Sb}_{2} \mathrm{Se}_{3}$ device exhibit smaller and less frequency dependent capacitances, indicating that the growth of $\mathrm{Sb}_{2} \mathrm{Se}_{3}$ nanorods reduces the defect density in the $\mathrm{Sb}_{2} \mathrm{Se}_{3}$ absorber or at its surface.

We further performed the capacitance-voltage $(C-V)$ profiling and deep-level capacitance profiling (DLCP) measurements on these devices for characterizing the defects. In general, the $C-V$ measurement is relation to free carriers, junction interface defects and bulk defects, while DLCP measurement is less sensitive to the junction interface defects ${ }^{27}$. As shown in Fig. $4 \mathrm{~d}$, the $N_{\text {DLCP }}$ values for these three devices are in the range of $4 \times 10^{14}$ to $2 \times$ $10^{15} \mathrm{~cm}^{-3}$, which are lower than the values obtained for reference samples of $\mathrm{Sb}_{2} \mathrm{Se}_{3}$ grown on $\mathrm{ZnO}$ or $\mathrm{TiO}_{2}$ layer as well as for $\mathrm{Sb}_{2} \mathrm{Se}_{3}$ deposited by thermal evaporation on Mo substrate $(4.6 \times$ $10^{15}$ to $\left.1.1 \times 10^{17} \mathrm{~cm}^{-3}\right)^{12,17,28}$. This suggests that the CSSprocessed $\mathrm{Sb}_{2} \mathrm{Se}_{3}$ absorbers on Mo substrate have a lower bulk defect density. On the other hand, $N_{\text {DLCP }}$ for TF- $\mathrm{Sb}_{2} \mathrm{Se}_{3}$ device was a little higher than that for $\mathrm{M}-\mathrm{Sb}_{2} \mathrm{Se}_{3}$ and $\mathrm{NA}-\mathrm{Sb}_{2} \mathrm{Se}_{3}$ devices, indicating the reduced bulk defect densities due to the evolution of $\mathrm{Sb}_{2} \mathrm{Se}_{3}$ from thin films to nanorod array structure. However, the $N_{\mathrm{CV}}$ values were much higher than the $N_{\mathrm{DLCP}}$ values for these three devices, indicating serious interface defects present at the $\mathrm{CdS} / \mathrm{Sb}_{2} \mathrm{Se}_{3}$ interface. The depletion width $\left(W_{\mathrm{d}}\right)$ is mainly located in the $\mathrm{Sb}_{2} \mathrm{Se}_{3}$ region at the $\mathrm{CdS} / \mathrm{Sb}_{2} \mathrm{Se}_{3}$ junction interface since the doping density of CdS is much higher than that of the $\mathrm{Sb}_{2} \mathrm{Se}_{3}$ absorbers ${ }^{16,29,30}$. Hence, the interfacial defect density could be calculated to be $2.77 \times 10^{12} \mathrm{~cm}^{-2}, 2.85 \times 10^{12} \mathrm{~cm}^{-2}$ and $3.21 \times$ $10^{12} \mathrm{~cm}^{-2}$ for $\mathrm{TF}-\mathrm{Sb}_{2} \mathrm{Se}_{3}, \mathrm{M}-\mathrm{Sb}_{2} \mathrm{Se}_{3}$ and $\mathrm{NA}-\mathrm{Sb}_{2} \mathrm{Se}_{3}$ devices, respectively. These values are higher than those of $\mathrm{CdS} / \mathrm{Sb}_{2} \mathrm{Se}_{3}$, $\mathrm{ZnO} / \mathrm{Sb}_{2} \mathrm{Se}_{3}$ or $\mathrm{TiO}_{2} / \mathrm{Sb}_{2} \mathrm{Se}_{3}$ in superstrate configurations, indicating that much more interface state activity can be expected for CBD-CdS buffer grown on $\mathrm{Sb}_{2} \mathrm{Se}_{3}$ absorbers ${ }^{12}$.

$\mathrm{CdS} / \mathrm{Sb}_{2} \mathrm{Se}_{3}$ junction interface. To explore the coverage of CBDCdS layer coated on the $\mathrm{Sb}_{2} \mathrm{Se}_{3}$ nanorod surface and the interdiffusion of elements at the $\mathrm{CdS} / \mathrm{Sb}_{2} \mathrm{Se}_{3}$ interface, we employed SEM, TEM, and high-angle annular dark-field scanning transmission electron microscope (HAADF-STEM) equipped with energy-dispersive spectroscopy (EDX) to characterize the interface of our CdS-coated $\mathrm{Sb}_{2} \mathrm{Se}_{3}$ nanorod array samples. As shown in Fig. 5a, b, the CBD growth procedure yields a uniform, dense, and pin-hole free CdS film, and the CdS layer completely covers the $\mathrm{Sb}_{2} \mathrm{Se}_{3}$ nanorod array surface, yielding a $\mathrm{CdS} / \mathrm{Sb}_{2} \mathrm{Se}_{3}$ core-shell structure. The morphology of the CdS film reveals a fine-grain accumulated structure. The TEM image (Fig. $5 c$, d) displays that the thickness of the CdS coated at the top of the $\mathrm{Sb}_{2} \mathrm{Se}_{3}$ nanorods is about 50 to $60 \mathrm{~nm}$. More details on the CdS film growth on the $\mathrm{Sb}_{2} \mathrm{Se}_{3}$ nanorod arrays reveal that the CBD-CdS is not only present on top of the nanorods but also penetrates into the space between the nanorods and conformally coats the sidewalls of the nanorods and in the valleys on the bottom compact layer, making the cell at least partially a radial junction cell. The uniform and complete coverage of CdS layer suggests good adhesion and well defined junction formation between the $\mathrm{Sb}_{2} \mathrm{Se}_{3}$ nanorod array and the CdS buffer layer.

A rectangular area in the Z-contrast HAADF cross-sectional image at the $\mathrm{CdS} / \mathrm{Sb}_{2} \mathrm{Se}_{3}$ nanorod interface was chosen to analyze the Sb, Se, Cd, and S element distribution. As shown in Fig. 5e, element spatial mapping of Se, Cd, and S shows sharp edges, indicating negligible interfacial inter-diffusion of these three elements. On the contrary, the $\mathrm{Sb}$ element mapping exhibits an obvious two-zone behavior in the $\mathrm{CdS} / \mathrm{Sb}_{2} \mathrm{Se}_{3}$ nanorod interface region, suggesting $\mathrm{Sb}$-diffusion into the $\mathrm{CBD}-\mathrm{CdS}$ layer. This phenomenon is quite different from the superstrate $\mathrm{CdS} / \mathrm{Sb}_{2} \mathrm{Se}_{3}$ heterojunction case, in which the $\mathrm{Cd}, \mathrm{S}, \mathrm{Sb}$, and Se elements mix together to form a thin n-type inter-diffusion layer and a buried homojunction at the interface, dictating charge separation and device performance in superstrate $\mathrm{CdS} / \mathrm{Sb}_{2} \mathrm{Se}_{3}$ thin film solar cells. The presence of $\mathrm{Sb}$ in the whole CBD-processed CdS buffer layer can be attributed to the dissolution of $\mathrm{Sb}_{2} \mathrm{Se}_{3}$ in the alkaline precursor solution (Supplementary Table 2). During the CBD process, some ammonia was added into the precursor solution to supply a suitable environment for the chemical reactions, and thus it also reacted with the precursor to form surface growth complexes $^{31,32}$. For reference, the metal chalcogenide was 
a
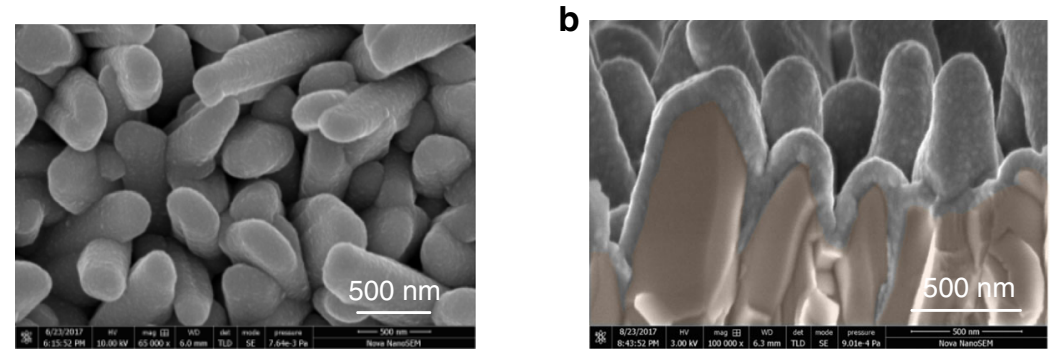

C
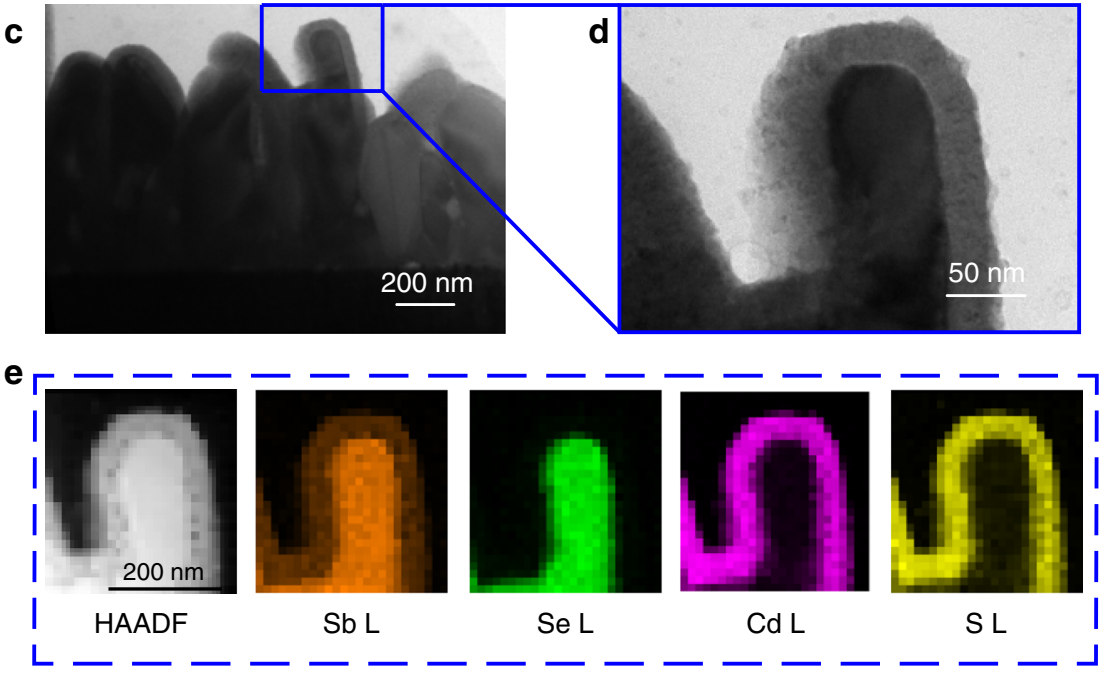

Fig. 5 Characterization of $\mathrm{CdS} / \mathrm{Sb}_{2} \mathrm{Se}_{3}$ junction interface. $\mathbf{a}$, b Top-view (a) and cross-sectional (b) $\mathrm{SEM}$ images of $\mathrm{CdS}$ buffer deposited on $\mathrm{Sb}_{2} \mathrm{Se} \mathrm{e}_{3}$ nanorod arrays. c-e TEM (c, d) and HAADF-STEM image and energy-dispersive spectroscopy elemental mapping (e) of the $\mathrm{CdS} / \mathrm{Sb}_{2} \mathrm{Se}_{3}$ junction interface. Elements detected: Sb L, Se L, Cd L, and S L

dissolved in hydrazine or ammonia sulfide solution through the formation of highly soluble metal chalcogenide complexes at a molecular level ${ }^{33-35}$. A similar dissolution process is expected to occur in the reaction of $\mathrm{Sb}_{2} \mathrm{Se}_{3}$ with $\mathrm{NH}_{4}{ }^{+}$during the deposition of the CdS layer in an ammonia solution.

Surface modification of $\mathrm{Sb}_{2} \mathrm{Se}_{3}$ nanorod arrays by thin ALD$\mathrm{TiO}_{2}$. In order to address the issue of $\mathrm{Sb}$ diffusion and the concomitant high interface defect density, a very thin atomic layer deposited (ALD) $\mathrm{TiO}_{2}$ layer was introduced between the $\mathrm{Sb}_{2} \mathrm{Se}_{3}$ nanorod array absorber and the CdS buffer to protect the $\mathrm{Sb}_{2} \mathrm{Se}_{3}$ from directly contacting the $\mathrm{NH}_{4}{ }^{+}$ions during the deposition of the CdS layer by CBD method. The EDX line scan analysis shows that the Sb content in the CdS layer was reduced for the CdS shell grown on $\mathrm{ALD}-\mathrm{TiO}_{2}$ modificated $\mathrm{Sb}_{2} \mathrm{Se}_{3}$ nanorod (Supplementary Figure 6). The decrease of $\mathrm{Sb}$ content in the $\mathrm{CdS}$ shell indicated that the thin $\mathrm{ALD}-\mathrm{TiO}_{2}$ could efficiently reduce the dissolution of $\mathrm{Sb}_{2} \mathrm{Se}_{3}$ during the CBD process. Moreover, the corrosion rate of $\mathrm{Sb}_{2} \mathrm{Se}_{3}$ layer in the ammonia solutions is slightly decreased after performing 20 cycles of $\mathrm{TiO}_{2}$ (Supplementary Figure 7 and Supplementary Table 2). Figure 6b, c exhibit the topview and cross-sectional images of the $\mathrm{Sb}_{2} \mathrm{Se}_{3}$ solar cells after applying all steps to a successfully completed fabrication. The device exhibits a stamp-like nanopatterned surface morphology and fewer holes and gaps are observed in the cross-sectional image, suggesting that the $\mathrm{CBD}$-processed $\mathrm{CdS}$ and sputtered $\mathrm{ZnO} / \mathrm{ZnO}: \mathrm{Al}$ completely covers the top of the $\mathrm{Sb}_{2} \mathrm{Se}_{3}$ nanorods as well as the lower parts within the space between nanorods.

Figure $6 \mathrm{~d}$ displays the $J-V$ curve of our best device in this work under simulated AM1.5 G solar illumination. This device was fabricated with 20 cycles of $\mathrm{ALD} \mathrm{TiO}_{2}$ on the $\mathrm{Sb}_{2} \mathrm{Se}_{3}$ absorber prior to the deposition of the CdS buffer. The cell exhibits a $V_{\mathrm{OC}}$ of $0.40 \mathrm{~V}$, a $J_{\mathrm{SC}}$ of $32.58 \mathrm{~mA} \mathrm{~cm}^{-2}$, a FF of $70.3 \%$, resulting in an overall power-conversion efficiency of $9.2 \%$, which has independently been verified by National Institute of Metrology of China (Supplementary Figure 8). A histogram of the device efficiencies obtained from 100 individually fabricated devices is shown in Fig. $6 \mathrm{f}$. The average $V_{\mathrm{OC}}, J_{\mathrm{SC}}, \mathrm{FF}$, and conversion efficiency were $399 \pm 33 \mathrm{mV}, 29.80 \pm 3.36 \mathrm{~mA} \mathrm{~cm}^{-2}, 64.46 \pm 12.01 \%$ and $7.69 \pm$ $1.56 \%$, respectively. Figure 6e depicts the corresponding EQE spectrum for the champion solar cell. It exhibits a broad plateau of over $85 \%$ between $550 \mathrm{~nm}$ and $900 \mathrm{~nm}$ and the integrated current density reaches a value as high as $31.48 \mathrm{~mA} \mathrm{~cm}^{-2}$. The photoresponse in the plateau region is higher than that of $\mathrm{Sb}_{2} \mathrm{Se}_{3}$ solar cells in a superstrate configuration and is comparable with that of CdS/CIGS thin film solar cells prepared in our laboratory with an efficiency of 15\%, as shown in Supplementary Figure 9. Nonetheless, there is large current loss at wavelengths below 550 $\mathrm{nm}$ due to strong parasitic absorption of the CdS buffer since the electron-hole pairs generated in the CdS layer are not collected. Therefore, it is desirable to replace the CdS with another wide band gap buffer material for further optimization.

Compared with the device without $\mathrm{ALD}-\mathrm{TiO}_{2}$ (Fig. 4, Supplementary Figure 10), the enhancement in conversion efficiency mainly results from an increase in $\mathrm{V}_{\mathrm{OC}}$ and $\mathrm{FF}$, which is tentatively attributed to the reduction of dissolution of $\mathrm{Sb}_{2} \mathrm{Se}_{3}$ during the $\mathrm{CBD}$ process and/or the reduction of shunt paths by the $\mathrm{ALD}-\mathrm{TiO}_{2}$ of the surface defects on the $\mathrm{Sb}_{2} \mathrm{Se}_{3}$ nanorods (the dangling bonds at the tips of the $\left(\mathrm{Sb}_{4} \mathrm{Se}_{6}\right)_{n}$ nanoribbons). As shown in Supplementary Figure 11, Kelvin probe force microscope (KPFM) was employed to study the surface properties of the $\mathrm{Sb}_{2} \mathrm{Se}_{3}$ nanorod array surfaces before and after the deposition 
a

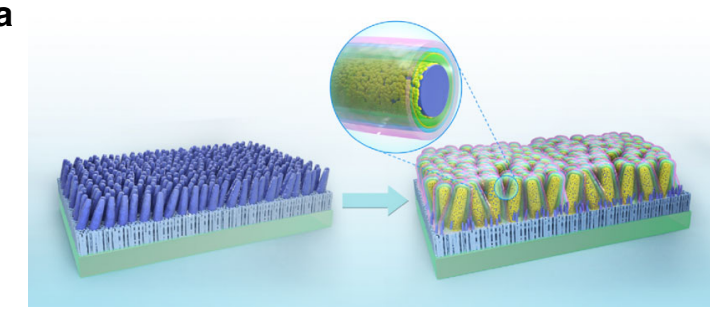

d

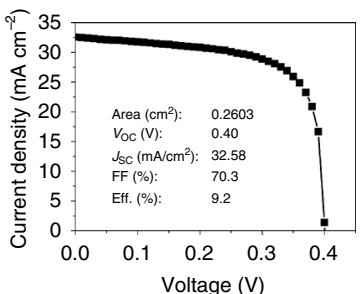

e





f

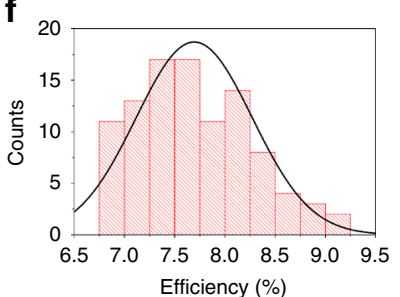

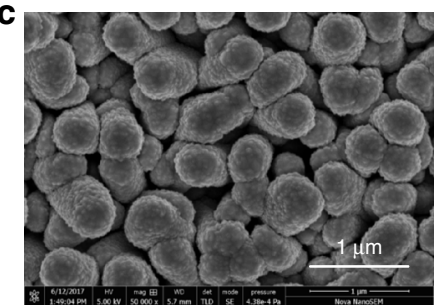

$\mathbf{g}$

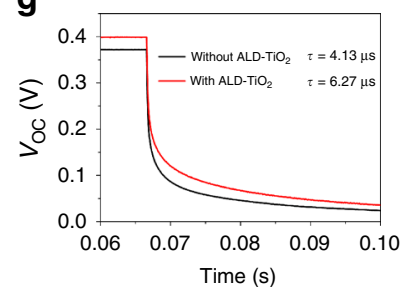

Fig. 6 Solar cell structure and mechanistic investigation of $\mathrm{ALD}-\mathrm{TiO}_{2}$ on $\mathrm{Sb}_{2} \mathrm{Se}_{3}$ nanorod arrays. a Schematic of the $\mathrm{Sb}_{2} \mathrm{Se}_{3} \mathrm{nanorod}$ arrays on $\mathrm{Mo}$-coated glass and finished $\mathrm{Sb}_{2} \mathrm{Se}_{3} / \mathrm{CdS}$ core/shell nanorod array solar cells. b, c Cross-sectional (b) and top view (c) SEM images of the completed $\mathrm{CdS}_{\mathrm{S}} \mathrm{Sb}_{2} \mathrm{Se}_{3}$ solar cells. d, e J-V curve (d) and EQE spectrum (e) of the champion device (area $=0.2603 \mathrm{~cm}^{2}$ ). $\mathbf{f}$ Histogram of device efficiency over 100 individually fabricated solar cells. $\mathbf{g} V_{\mathrm{OC}}$ decay curves of the solar cells with and without ALD-TiO 2 layer

of 20 cycles of $\mathrm{TiO}_{2}$. While the average roughness stays at the same value $(100 \mathrm{~nm})$, the average surface potential difference decreases from 28.8 to $10.4 \mathrm{mV}$ after the deposition of the thin ALD-TiO ${ }_{2}$. This suggests that a thin layer of ALD-TiO improves $^{2}$ the surface band bending at the side walls and reduces the surface defects at the tips of the $\mathrm{Sb}_{2} \mathrm{Se}_{3}$ nanorods ${ }^{15,36}$. A surface potential difference of $280 \mathrm{mV}$ was observed between the $\mathrm{Sb}_{2} \mathrm{Se}_{3}$ layer before and after thin $\mathrm{ALD}-\mathrm{TiO}_{2}$ modification. Taking into account of the valence band maximum (VBM) and band gap of $\mathrm{Sb}_{2} \mathrm{Se}_{3}$, we obtained the energy level diagram of the $\mathrm{CdS} /\left(\mathrm{TiO}_{2}\right)$ $\mathrm{Sb}_{2} \mathrm{Se}_{3}$ interface (Supplementary Figure 12). The conduction band minimum (CBM) of $\mathrm{Sb}_{2} \mathrm{Se}_{3}$ layer is shifted by about $0.13 \mathrm{eV}$ towards to the vacuum level after $\mathrm{ALD}-\mathrm{TiO}_{2}$ modification. The downshifted of the CBM could decrease the conduction band offset at buffer/absorber interface, and lead to the increased fill factor. Furthermore, the possible shunt paths for the CdS/Sb $\mathrm{Se}_{2}$ junction with and without $\mathrm{ALD}-\mathrm{TiO}_{2}$ were detected by conductive atomic force microscopy (C-AFM). For the sample without $\mathrm{ALD}-\mathrm{TiO}_{2}$ some white dots, representing the detected current, are observed (Supplementary Figure 13), indicating the poor coverage of $\mathrm{CdS}$ and the presence of shunt leakage due to local discontinuity or pinholes in the CdS buffers. On the contrary, with the insertion of thin $\mathrm{ALD}-\mathrm{TiO}_{2}$ between the CdS buffer and the $\mathrm{Sb}_{2} \mathrm{Se}_{3}$ nanorod array absorber, the white dotted area decreases or even vanishes, suggesting reduced shunt leakage.

The ALD- $\mathrm{TiO}_{2}$ layer may also passivate the surface defects of the $\mathrm{Sb}_{2} \mathrm{Se}_{3}$ layer. This can be confirmed by the $\mathrm{V}_{\mathrm{OC}}$ decay measurement, which is related to the carrier recombination rate and the carrier lifetimes. Figure $6 \mathrm{~g}$ displays the $\mathrm{V}_{\mathrm{OC}}$ decay curves of two representative $\mathrm{Sb}_{2} \mathrm{Se}_{3}$ solar cells, with and without ALD$\mathrm{TiO}_{2}$ thin layer. The cell with 20 cycles of ALD-TiO ${ }_{2}$ layer exhibits an obvious longer decay time than the cell without ALD$\mathrm{TiO}_{2}$. Furthermore, as the thin ALD-TiO ${ }_{2}$ layer is compact and has excellent film conformity due to its layer-by-layer growth, it is expected to reduce or even prevent the chemical reaction of $\mathrm{Sb}_{2} \mathrm{Se}_{3}$ with the growth solution during the CBD deposition of the CdS buffer layer, leading to a more pure CdS buffer layer. The influence of doping of $\mathrm{Sb}$ in CdS buffer layers has not been exclusively demonstrated thus far and requires more investigation in the near future. We investigate the stability of the $\mathrm{Sb}_{2} \mathrm{Se}_{3}$



Fig. 7 Device stability. Stability of representative $\mathrm{Sb}_{2} \mathrm{Se}_{3}$ solar cells without and with $\mathrm{TiO}_{2}$ modification

nanorod array based solar cells. As shown in Fig. 7, the normalized efficiency of the $\mathrm{CdS} / \mathrm{Sb}_{2} \mathrm{Se}_{3}$ solar cell with $\mathrm{TiO}_{2}$ modification hold a slightly higher value ( $\sim 97 \%$ of its initial value) than that of the device without $\mathrm{TiO}_{2}$ modification $(\sim 94 \%$ of its initial value) after storage in air for more than $500 \mathrm{~h}$.

\section{Discussion}

In summary, we have demonstrated the fabrication of high quality solar cells employing a $1 \mathrm{D} \mathrm{Sb}_{2} \mathrm{Se}_{3}$ nanorod array absorber with a height of more than $1000 \mathrm{~nm}$ in the substrate configuration. TEM analysis indicated that the growth of nanorods is along the [001] direction. We propose a split growth model based on the morphology evolution from the thin film to a nanorod array. The solar cells exhibited excellent EQE spectra in the whole working wavelength range (higher than $85 \%$ between 550 and $900 \mathrm{~nm}$ ), indicating that there is long-range carrier transport along the [001] direction. Furthermore, we found that $\mathrm{Sb}$ diffuses into the CdS buffer due to the solubility of $\mathrm{Sb}_{2} \mathrm{Se}_{3}$ in the alkaline solution during the CBD process. A very thin $\mathrm{TiO}_{2}$ layer deposited by ALD was introduced prior to the deposition of CdS buffer layer, leading to an improved $V_{\mathrm{OC}}, \mathrm{FF}$ as well as conversion efficiency. This cell design and these results provide important 
progress towards the understanding and application of 1Dstructured $\mathrm{Sb}_{2} \mathrm{Se}_{3}$ crystals.

\section{Methods \\ Solar cell fabrication. The bilayer Mo back contacts were prepared by a two-step magnetron sputtering process, which consisted of high working pressure $(2.0 \mathrm{~Pa})$ and low working pressure $(0.3 \mathrm{~Pa})$ process. The total thickness of Mo was about $1000 \mathrm{~nm}$. A Mo selenization process was carried out at $620^{\circ} \mathrm{C}$ for $20 \mathrm{~min}$ to form about $20 \mathrm{~nm}$ thick $\mathrm{MoSe}_{2}$ layer prior to the deposition of $\mathrm{Sb}_{2} \mathrm{Se}_{3}{ }^{17}$. The $\mathrm{Sb}_{2} \mathrm{Se}_{3}$ absorber layers were grown on selenized Mo-coated glass by using a homemade CSS system. In CSS system, the thermocouple was inserted into the graphite plate to directly detect the temperatures of substrate and evaporation source, respec- tively. The temperatures of $\mathrm{Sb}_{2} \mathrm{Se}_{3}$ source and substrate holder were controlled by two sets of lamp heaters and thermocouples. The distance between the source and the sample holder was $11 \mathrm{~mm}$. We started the deposition when the pressure was below $10^{-2} \mathrm{~Pa}$. First, the source and sample holder were warmed up to $480^{\circ} \mathrm{C}$ and $270{ }^{\circ} \mathrm{C}$, respectively, in 200 seconds, and maintained at the high temperatures for hundreds of seconds to obtain the desired $\mathrm{Sb}_{2} \mathrm{Se}_{3}$ absorber thickness. The thick- nesses of the $\mathrm{Sb}_{2} \mathrm{Se}_{3}$ layers in the range of $200-2000 \mathrm{~nm}$ were controlled by adjusting the duration ranging from $60-180 \mathrm{~s}$ at high temperature. The samples were taken out after cooling down to about $150^{\circ} \mathrm{C}$ in about $1 \mathrm{~h}$. After that, the $\mathrm{Sb}_{2} \mathrm{Se}_{3}$ samples were coated with $60 \mathrm{~nm}$ of CdS by chemical bath deposition at a bath temperature of $70^{\circ} \mathrm{C}$. Window layers of $\mathrm{HR}$ and $\mathrm{LR} \mathrm{ZnO}$ films were sputtered from pure $\mathrm{ZnO}$ and $\mathrm{ZnO}$ :Al targets $\left(\mathrm{Al}_{2} \mathrm{O}_{3} 2 \mathrm{wt} \%\right.$-doped). Top Ag grids of the solar cells were finally formed by thermal evaporation. The complete $\mathrm{Sb}_{2} \mathrm{Se}_{3}$ solar cells have a structure of glass/Mo/MoSe $/ \mathrm{Sb}_{2} \mathrm{Se}_{3} / \mathrm{HR}-\mathrm{ZnO} / \mathrm{LR}-\mathrm{ZnO} / \mathrm{Ag}$. TiO ${ }_{2}$ was deposited at $150^{\circ} \mathrm{C}$ in a homemade ALD reactor system, which using titanium isopropoxide (TTIP) and $\mathrm{H}_{2} \mathrm{O}$ as Ti and $\mathrm{O}$ precursors, respectively. One deposition cycle involves a $\mathrm{H}_{2} \mathrm{O}$ pulse of $0.5 \mathrm{~s}$, a $\mathrm{N}_{2}$ pulse of $60 \mathrm{~s}$, a TTIP pulse of $0.5 \mathrm{~s}$, and $60 \mathrm{~s}$ of $\mathrm{N}_{2}$ purging, and each deposition cycle was started with a $\mathrm{H}_{2} \mathrm{O}$ pulse and ter- minated with a TTIP pulse. About $2 \mathrm{~nm}$ thickness of $\mathrm{TiO}_{2}$ coating was deposited in 20 cycles.}

Material and device characterization. SEM observations were performed on a FEI Nova NANOSEM 450 field-emission microscope and the TEM measurements were carried out on a FEI Tecnai G2 transmission electron microscope. The optical properties were recorded using a Perkin-Elmer Lambda 950 spectrophotometer. The XRD data were collected with a Bruker D8 Advance diffractometer. The current density-voltage $(J-V)$ measurement was performed using an AM1.5 solar simulator equipped with a $300 \mathrm{~W}$ Xenon lamp (Model No. XES-100S1, SAN-EI, Japan). The EQE was measured by an Enlitech QER3011 system equipped with a $150 \mathrm{~W}$ xenon light source. Capacitance-voltage $(C-V)$ measurement was performed on Agilent B1500A Semiconductor device analyzer in the dark at room temperature. Carrier-lifetime measurements were performed using the DN-AE01 Dyenamo toolbox with a white light-emitting diode (Luxeon Star 1W) as the light source ${ }^{37,38}$.

Simulation methods. All calculations of $\mathrm{Sb}_{2} \mathrm{Se}_{3}$ growing on the Mo (110) were calculated by the VASP. The DFT calculations employed the Perdew-BurkeErnzerhof (PBE) generalized gradient approximation (GGA) exchange-correlation functional and the projector-augmented wave (PAW) method. An energy cut-off of $500 \mathrm{eV}$ was applied for the plane wave expansion of the wave functions. $2 \times 4 \times 1$ Monkhorst-pack mesh for k-point sampling are required to relaxation all models of the $\mathrm{Sb}_{2} \mathrm{Se}_{3}$ sheet growing on the Mo (110) with or without Se and Sb layers.

\section{Data availability}

The data supporting this study are available from the authors on request.

Received: 19 July 2018 Accepted: 5 December 2018

Published online: 10 January 2019

\section{References}

1. Green, M. A. et al. Solar cell efficiency tables (version 51), Prog. Photovolt. Res. Appl. 26, 3-12 (2018)

2. Solar Frontier. Solar Frontier achieves world record thin-film solar cell efficiency of $22.9 \%$. Solar Frontier http://www.solar-frontier.com/eng/news/ 2017/1220_press.html, Accessed June 2018 (2017).

3. Zhou, Y. et al. Solution-processed antimony selenide heterojunction solar cells. Adv. Energy Mater. 4, 1079-1083. (2014).

4. Liang, G. X. et al. Thermally induced structural evolution and performance of $\mathrm{Sb}_{2} \mathrm{Se}_{3}$ films and nanorods prepared by an easy sputtering method. Sol. Energy Mater. Sol. Cells 174, 263-270 (2018).

5. Yuan, C., Zhang, L., Liu, W. \& Zhu, C. Rapid thermal process to fabricate Sb2Se3 thin film for solar cell application. Sol. Energy 137, 256-260 (2016).
6. Birkett, M. et al. Band gap temperature-dependence of close-space sublimation grown $\mathrm{Sb}_{2} \mathrm{Se}_{3}$ by photo-reflectance. APL Mater. 6, 084901 (2018).

7. Wang, X., Tang, R., Wu, C., Zhu, C. \& Chen, T. Development of antimony sulfide-selenide $\mathrm{Sb}_{2}(\mathrm{~S}, \mathrm{Se})_{3}$-based solar cells. J. Energy Chem. 27, 713-721 (2018).

8. Shen, K. et al. Mechanisms and modification of nonlinear shunt leakage in $\mathrm{Sb}_{2} \mathrm{Se}_{3}$ thin film solar cells,. Sol. Energy Mater. Sol. Cells 186, 58-65 (2018).

9. Sarah, M., Nair, M. T. S. \& Nair, P. K. Antimony selenide absorber thin films in all-chemically deposited solar cells. J. Electrochem. Soc. 156, H327-H332 (2009).

10. Bindu, K., Nair, M. T. S. \& Nair, P. K. Chemically deposited Se thin films and their use as a planar source of selenium for the formation of metal selenide layers. J. Electrochem. Soc., 153, C526-C534 (2006).

11. Choi, Y. C. et al. $\mathrm{Sb}_{2} \mathrm{Se}_{3}$-sensitized inorganic-organic heterojunction solar cells fabricated using a single-source precursor. Angew. Chem. Int. Ed. 53, 1329-1333 (2014)

12. Wang, L. et al. Stable $6 \%$-efficient $\mathrm{Sb}_{2} \mathrm{Se}_{3}$ solar cells with a $\mathrm{ZnO}$ buffer layer. Nat. Energy 2, 17046 (2017)

13. Chen, C. et al. $6.5 \%$ certified efficiency $\mathrm{Sb}_{2} \mathrm{Se}_{3}$ solar cells using $\mathrm{PbS}$ colloidal quantum dot film as hole-transporting layer. ACS Energy Lett. 2, 2125-2132 (2017).

14. Wen, X. et al. Vapor transport deposition of antimony selenide thin film solar cells with 7.6\% efficiency. Nat. Commun. 9, 2179 (2018).

15. Zhou, Y. et al. Thin-film $\mathrm{Sb}_{2} \mathrm{Se}_{3}$ photovoltaics with oriented one-dimensional ribbons and benign grain boundaries. Nat. Photon 9, 409-415 (2015).

16. Chen, C. et al. Characterization of basic physical properties of $\mathrm{Sb}_{2} \mathrm{Se}_{3}$ and its relevance for photovoltaics, Front. Optoelectron 10, 18-30 (2017).

17. Li, Z. et al. $\mathrm{Sb}_{2} \mathrm{Se}_{3}$ thin film solar cells in substrate configuration and the back contact selenization. Sol. Energy Mater. Sol. Cells 161, 190-196 (2017).

18. Zhai, T. et al. Single-crystalline $\mathrm{Sb}_{2} \mathrm{Se}_{3}$ nanowires for high-performance field emitters and photodetectors. Adv. Mater. 22, 4530-4533 (2010).

19. Xie, Q. et al. Polymer-controlled growth of $\mathrm{Sb}_{2} \mathrm{Se}_{3}$ nanoribbons via a hydrothermal process. J. Cryst. Growth 252, 570-574 (2003).

20. Kresse, G. \& Hafner, J. Ab initio molecular dynamics for liquid metals. Phys. Rev. B 47, 558-561 (1993).

21. Zhu, J. et al. Optical absorption enhancement in amorphous silicon nanowire and nanocone arrays. Nano Lett. 9, 279-282 (2009).

22. Liu, X. et al. Improving the performance of $\mathrm{Sb}_{2} \mathrm{Se}_{3}$ thin film solar cells over $4 \%$ by controlled addition of oxygen during film deposition. Prog. Photovolt. Res. Appl. 23, 2892 (2015).

23. Liu, X. et al. Enhanced $\mathrm{Sb}_{2} \mathrm{Se}_{3}$ solar cell performance through theory-guided defect control. Prog. Photovolt. Res. Appl. 25, 861-870 (2017).

24. Proskuryakov, Y. Y. et al. Impedance spectroscopy of thin-film CdTe/ CdS solar cells under varied illumination. J. Appl. Phys. 106, 024504 (2009).

25. Walter, T., Herberholz, R., Müller, C. \& Schock, H. W. Determination of defect distributions from admittance measurements and application to $\mathrm{Cu}(\mathrm{In}$, Ga) $\mathrm{Se}_{2}$ based heterojunctions. J. Appl. Phys. 80, 4411-4420 (1996).

26. Kneisel, J., Siemer, K., Luck, I. \& Braunig, D. Admittance spectroscopy of efficient $\mathrm{CuInS}_{2}$ thin film solar cells. J. Appl. Phys. 88, 5474-5481 (2000).

27. Duan, H. S. et al. The role of sulfur in solution-processed $\mathrm{Cu}_{2} \mathrm{ZnSn}(\mathrm{S}, \mathrm{Se})_{4}$ and its effect on defect properties. Adv. Funct. Mater. 23, 1466-1471 (2013).

28. Chao, C. et al. Accelerated optimization of $\mathrm{TiO}_{2} / \mathrm{Sb}_{2} \mathrm{Se}_{3}$ thin film solar cells by high-throughput combinatorial approach. Adv. Energy Mater. 7, 1700866 (2017).

29. Cwil, M., Igalson, M., Zabierowski, P. \& Siebentritt, S. Charge and doping distributions by capacitance profiling in $\mathrm{Cu}(\mathrm{In}, \mathrm{Ga}) \mathrm{Se}_{2}$ solar cells. J. Appl. Phys. 103, 063701 (2008).

30. Decock, K., Zabierowski, P. \& Burgelman, M. Modeling metastabilities in chalcopyrite-based thin film solar cells. J. Appl. Phys. 111, 043703 (2012).

31. Maticiuc, N., Katerski, A., Danilson, M., Krunks, M. \& Hiie, J. XPS study of $\mathrm{OH}$ impurity in solution processed CdS thin films. Sol. Energy Mater. Sol. Cells 160, 211-216 (2017).

32. Ortega Borges, R. \& Lincot, D. Mechanism of chemical bath deposition of cadmium sulfide thin films in the ammonia-thiourea system: in situ kinetic study and modelization. J. Electrochem. Soc. 140, 3464-3473 (1993).

33. Xia, Z. et al. Generalized water-processed metal chalcogenide complexes: synthesis and applications. Chem. Mater. 27, 8048-8057 (2015).

34. Mitzi, D. B. Solution processing of chalcogenide semiconductors via dimensional reduction. Adv. Mater. 21, 3141-3158 (2009).

35. Protesescu, L. et al. Atomistic description of thiostannate-capped CdSe nanocrystals: retention of four-coordinate $\mathrm{SnS}_{4}$ motif and preservation of Cdrich stoichiometry. J. Am. Chem. Soc. 137, 1862-1874 (2015).

36. Jiang, C.-S. et al. How grain boundaries in $\mathrm{Cu}(\mathrm{In}, \mathrm{Ga}) \mathrm{Se}_{2}$ thin films are charged: Revisit. Appl. Phys. Lett. 101, 033903 (2012).

37. Freitag, M. et al. Dye-sensitized solar cells for efficient power generation under ambient lighting. Nat. Photon. 11, 372 (2017). 
38. Boschloo, G., Häggman, L. \& Hagfeldt, A. Quantification of the effect of 4-tert-butylpyridine addition to $\mathrm{I}^{-} / \mathrm{I}^{3-}$ redox electrolytes in dye-sensitized nanostructured $\mathrm{TiO}_{2}$ solar cells. J. Phys. Chem. B 110, 13144-13150 (2006).

\section{Acknowledgements}

This work was supported by the Advanced Talents Incubation Program of the Hebei University (801260201001), National Natural Science Foundation of China (NSFC No.61804040), Scientific Research Foundation for the Returned Overseas Chinese Scholars (CG2015003004), and Natural Science Foundation of Hebei Province (No. E2016201028)

\section{Author contributions}

Z.L. and Y.M. conceived the idea and designed the experiments. Z.L., X.L. and G.L. performed most of the device fabrication and characterization. H.L., H.Z. and W.Y. conducted the $\mathrm{TiO}_{2}$ deposition. K.S. and X.S. assisted in the TEM and EDX mapping characterization and data analysis. J.G. and J.C. carried out the theoretical simulation and analyzed the results. Z.L., R.E.I.S., and Y.M. analyzed the overall results and wrote the paper. Y.M. supervised the project and all authors discussed the experiments and commented on the manuscript.

\section{Additional information}

Supplementary Information accompanies this paper at https://doi.org/10.1038/s41467018-07903-6.

Competing interests: The authors declare no competing interests.
Reprints and permission information is available online at http://npg.nature.com/ reprintsandpermissions/

Journal peer review information: Nature Communications thanks the anonymous reviewers for their contribution to the peer review of this work. Peer reviewer reports are available.

Publisher's note: Springer Nature remains neutral with regard to jurisdictional claims in published maps and institutional affiliations.

(C) The Author(s) 2019 